Online Journal of the Faculty of Arts and Social Sciences International University of Sarajevo

ISSN 1840-3719 / Volume 1 / No. 1 Fall 2008

\title{
Humour in the Prison: Brendan Behan Confesses
}

\section{Enrico Terrinoni University of Rome}

Evelyn Waugh, a British satirical writer with little working class connections, once remarked that "anyone who has been to an English public school will always feel comparatively at home in prison." Accordingly, he argued that it "is people brought up in the gay intimacy of the slums who find prison so soul destroying" (128). For all the wit of the paradox, its patronizing nuances spoil it of much of its intended comic potential. To speak of the "gay intimacy of the slums" is a way of looking down at the people actually living in the slums, as only a person with little knowledge of slum life would be capable of doing. This is why, as a member of the respectable London middle-class, Waugh might not have been surprised at hearing what an experienced Irish convict, Brendan Behan, had to say about him in a satirical ballad included in his play The Hostage - which took London by storm in 1958: "In our dreams we see Old Harrow, and we hear the crow's load caw / At the flower show our big marrow takes the prize from Evelyn Waugh" (Complete Plays 193). The song powerfully mocks at the typically highbrow arrogance of British upper classes, of which Waugh seems to be a symbol. Not only was Behan someone with much knowledge of both slum and prison life, but he was also an Irish nationalist and a socialist, and therefore represented in a way identitarian and political values that were in plain opposition to those of Waugh.

This way of starting a reflection on the comical aspects of Behan's writings helps us see that humour, especially black humour, often flourishes wherever we 
find conflicts and contrasts. Humour is always born out of oppositions, and it can indeed be argued that it always functions as an act of resistance to outside tragedy. Alternation of comical and dramatic scenes in the novel, as well as in the theatre tradition, is not only an infallible device supporting the structure of many successful texts, but also something that pertains to the very nature of existence itself. It being a sort of hidden force that keeps us from desperation, it is inevitably connected with the acknowledgement of widespread suffering and wretchedness, and provides a detaching response to it.

Brendan Behan, a writer of slum and working class background, is one of the leading Irish prison writers. More than that, as a former IRA Borstal Boy, he is in many ways an exponent of an Irish republican tradition based on the idea of prison endurance, alongside John Mitchel, Ernie O'Malley, Bobby Sands, Gerry Adams and many others.' He used to boast that he had been "in every respectable jail in the world," (qtd. in McCann 172) and when he was asked by an interviewer which prison he preferred, English or Irish, he answered: "English jails when you are young, and Irish jails when you are older" (qtd. in McCann 13).

Prisons and other institutions of confinement such as industrial schools, Magdalene's asylums, and English public schools, are places where the convicted guests are forced to deal with all possible restrictions of the concept of intimacy, especially in terms of intimate interactions and relationships. Rather than producing always, as one might well expect, general discomfort and despair, such a deprivation may often prompt, at least in fiction, very funny accounts. This is often the case with Behan. Prison intimacy being mostly a kind of self-intimacy, it can turn into a powerful tool of resistance. The negation of the right to privacy is sanctioned by prison bylaws and enforced by screws, a category of people Behan generally

\footnotetext{
' See Kearney 48-59; Farquharson 31-3.
} 
disliked. One of the contrasts out of which most of the fun emerges in Behan's representations of prison life, is the ironical Otherness - if I am allowed the use of this term in the present context - of the screws. He has often harsh words for them, and tends to address them with funny torrents of abusive language, like in the very beginning of Confessions of an Irish Rebel:

'You're for the governor in the morning,' said this dreary red-headed little Welsh Methodist bastard of a screw.

'Thanks for telling me,' said I, in an almost English accent, as sarcastically as I politely could, 'but I'm not for 'im in the morning or any other bloody time, you little Welsh puff'. (13)

In Behan's writings screws are often portrayed as utterly despicable characters, not just because they are those in charge, and as such have complete control on the privacy of the prisoners. Even solitary confinement cells hosting those lags who get the "number one", that is, bread-and-water diet, have spy-holes, and screws can decide to check on the prisoner at any moment. This can be particularly annoying on certain occasions, like when the convicted is busy accomplishing very personal tasks such as using the lavatory. In Borstal Boy Behan describes his own feelings in one of those circumstances, in a way that is on the verge between hatred and compassion, but still maintains a wry smile on the face: "I was anxious about the lavatory. The seat in a corner, in full view of the spy-hole. [...] I didn't like the idea of using the lavatory and that old John Bull's bastard of a copper looking in at me" (15).

A similar awkward situation occurs later on in the book when Brendan is left alone in his cold cell and thinks of having some self-produced sexual pleasure. Here the reader is gently allowed to perceive, through the lens of a teenager who is jailed in a foreign country for political reasons, not only what prison loneliness and 
discomfort were like, but also the prisoner's will to fight, with irony and courage as the only arms at his disposals, the violent threats of alienation of the starkly silent environment surrounding him:

It was cold sitting on the chair, after my dinner. [...] You were not let make down your bed and lie on it till the bell went at eight o'clock, but Lord Jesus, I was perished with the cold. I sat on my chair facing the door and pulled my mailbag up over my legs, and put my hands down the shirt. Not too far down, though (save for tonight), and besides it would be dangerous if a screw looked in the spy-hole at me. Not that that was against the rules - at least I hadn't heard it was - and even if the screws mentioned it, it was in a joke: but it would be embarrassing to have them see you, and they would more nor likely jeer the heart out of you for the rest of time. (ibid. 55-6)

Another reference to a similar situation occurs in the first chapter of Confessions. Here the protagonist, after having being released from Borstal, indulges his passion for drink with an unlikely drinking bout in the company of a British police inspector. At the end of the day, the two are "supposed to go straight to the jail" in Liverpool, but by Behan's own admission, they "called the respects to the local publicans on the way," and he ended up getting "so fughing drunk that they wouldn't let me into the prison." Behan records the event as "the first time I was ever refused admittance to the nick." Later on, the reader encounters something similar to the aforementioned Borstal recollection; but this time the protagonist seems to be a little more mature and self confident, or, to put it in Behan's own words, "kind of cocky and sure of myself":

I looked around the room. Bare concrete walls and floor again and the same wooden bench for a bed and a pillow of the same material. I coiled myself up, put my jacket behind my head, pulled the coarse blankets over me, contemplated committing a mortal sin, realised I was too drunk and fell into deep sleep. (21) 
Given Behan's notoriously flamboyant personality and his own talking gifts, it is not hard to imagine that the worst aspect of prison confinement might have been for him compulsory solitude and silence. His exuberant language and larger-thanlife personality can be considered perhaps as a reaction to such partial deprivation of interpersonal relationships during his youth. In Borstal Boy this is all very clear. In an early passage he admits to the fact that solitary confinement is something he just cannot stand: "I hoped they would open my door. Even if they were distributing nothing better than kicks or thumps, l'd prefer not to be left out, in my cold shroud of solitude. Fighting is better than loneliness" (8). In Brendan Behan's Island - the first of his three "talk books" or confessional publications which were mostly talked into a tape-recorder with the assistant of an editor - there occurs a powerful reference to a similar idea, which allows us to see the rootedness of Behan's rumbustiousness in his youthful slum life: "Ria had the hearse go round the block where we'd all lived years ago - happy, healthy, though riotous betimes - fighting being better than loneliness" (58).

The need for expressing feelings and ideas that have been silenced for so long due to imprisonment and forced solitude may be one of the reasons for Behan's ebullient and extravagant language. This might have influenced greatly also the style of his confessional writings, whose publication, we have to acknowledge, was "dictated" by other material circumstances. These were, for example, the writer's own difficulty in writing, given his physical illness (a combination of diabetes and love for the bottle), and the poor conditions of his health. Other reasons are connected with his publishers' despicable eagerness for more and more best-selling titles by the Irish turbulent genius, despite his precarious condition. 
Confessions usually give utterance to allegedly intimate feelings about some person or event. The process of confessing strongly implies a dimension of intimacy in that it entails the disclosure of aspects of one's private life, like sins for instance, or the admission of public acts like offences and crimes. Moreover, confessions always imply an audience. This could be an inspector in a police station, a jury in a court, a catholic priest in a confessional box, or even a reading public. In short, confessions are strictly linked to the idea of some sort of personal truth to be revealed. Yet, this truth has little to share with reality, it belonging to the realm of fictional representation through literary language.

Only the last of Behan's three dictated books refers overtly in the title to that sub-genre of narrative known as confessional writings. Confessions of an Irish Rebel is not strictly speaking the last book on which Behan worked, for after he still had some time and mental ability to tape Brendan Behan's New York, ${ }^{2}$ arguably the less interesting of the trilogy. In what other sense, then, is Confessions Behan's last book, apart from the fact that it was published a year after Brendan Behan's New York, in September 1965? Although most of Behan's works draw massively on personal experience and recollections, it might be argued that Confessions responds partly to an urgent need to say a final word about his own tragicomic life. John Brannigan explained that the book, together with Brendan Behan's Island and Richard Cork's Leg "produces a kind of epitaphic discourse" for death "was an important theme of his early writings, particularly as the product of political violence, but it became an intense preoccupation in his late writings" (153). The critic argues also that the book "finishes with a kind of epitaph of its own, in which Behan declares to his loved one, in sentimental quotation, 'I've been faithful to thee, after my fashion' " (161). I will return to the representation of love and its comical implications, which always go hand in hand with suffering and despair, later on. As 
regards the ever-present autobiographical tendency in Behan's writings, which is in a way always an effort of self-mockery, as well as a means for ironical critiques of the worlds and society, we need to answer the question of why one should consider Confessions a reliable source of information about the writer's intimate life.

It is a well established cliché among critics to compare the talk books to the rest of Behan's writings, and therefore consider them rather as publicity ventures which produced poor artistic results. The overwhelming comical register of such texts has much to do with the critical dismissal of them as minor works. They have often been described as anecdotal, repetitive and collaborative writings by which greedy publishers exploited a once-talented celebrity who had been unfortunately brought down by alcohol and publicity. It is indeed rare to find accounts of those works as experiments, no matter how successful, in oral literature. After all, one of the reasons why they were conceived in the first place was Behan's renowned ability as a storyteller and a raconteur.

One can easily agree that stories and tales are always better told if the teller is a mocker. Story, especially in Ireland, is another term for joke, and one cannot fail to acknowledge that the best of storytellers will always have a repertoire that, although anecdotal and repetitive, has to a certain extent to be funny. Moreover, a storyteller must have a listening audience, and an ideal audience for Behan's talk books, given the amount of songs, poems and bawdy jokes they include, should be a listening audience rather than a reading public. In other words, if those experiments have really proved partially unsuccessful in the eyes of readers, critics should take into account the fact that the very idea of taping Behan's stories, naturally jars with the filter of the printed page.

On the contrary, most of those privileged readers known as critics resorted in Behan's case to his repetitiveness as a writer, and in so doing showed quite clearly a

\footnotetext{
${ }^{2}$ See O'Connor 319.
} 
bias against someone who was now thought to be a dying alcoholic, and had been in the past an ex-republican and ex-socialist. Therefore, he had to have run out of ideas. His last texts, for all the editorial work by Behan's "literary midwife," Rae Jeffs, are still oral books, for all the contradictory nature of the description. Accordingly, they would need indeed some sort of an oral performance to be appreciated fully. This is why one feels that comparing Behan's written works to his talk books is a bit like comparing a footballer to a tennis player.

As a matter of fact, when Brendan Behan's Island appeared it received wide critical acclaim. Cyril Connolly praised the book as a testimony to the author's "instinctive kindness and charity" and his "strong personality that may even have a touch of greatness" (qtd. in O'Connor 251). This is a book that features clearly many aspects typical of oral literature. It starts with a ballad, and contains powerful jokes such as the following about the sectarian problems in Northern Ireland:

I remember a friend of mine was taking an English Catholic priest round the North some years ago and explaining to him how Catholics there were subject to intolerance and discrimination. The priest was horrified at the cases that were brought to his attention. One day, they were in this village and the local Catholic Chief Head Man had spent a good deal of time talking about the Protestants and their lack of toleration.

'Tell me,' said the priest, 'how many Protestants have you in this village'.

'One, Father,' said the Head Man, and leaning forward, he tapped the priest on the knee, 'but, with the help of God, we'll have him out by Christmas' (Island 168-9).

These words, coming from a man who described himself as an atheist during the day and a catholic at night, help us see how Behan's orality is a mark of his being a working class writer. The easygoing and fluid style of the story is unmistakably oral, and yet it actually works also on the written page. 
Northerner Louis MacNeice, possibly without knowing that massive parts of the book hadn't been written at all, captures the oral qualities of the experiment and suggests that Behan in this book "writes like a talker talking with plenty of hyperbole and emphasis, with humanity, gusto and formidable wit" (qtd. in O'Connor 251). Something similar could be said of Confessions, a book in which the work of Behan's editorial assistant is substantial, as she herself admits in her preface to the text. Despite this, it is probably the most successful of the three, it being the funniest, and is still reissued regularly in paperback editions in different countries.

Having said that in order to reassess the relevance of the talk books in a complete analysis of Behan's writings, we might turn to the question of confessional writing as a narrative that related to a certain extent to the concepts of admission, truth, and sincerity. Such expressions are all the more credible due to irony and jokes that function as exorcising devices on the one hand, while on the other help the reader feel "at home," so to speak, in the company of the storyteller.

Behan's stories about himself, and his recollections, alongside the many anecdotes about him, are perhaps the only way of inventing, and in fact constructing, a biography of him, no matter how reliable. Actually, Behan is more famous for what he has not accomplished, rather than for what he has really done. In Behan, fiction and truth, like stories and reality, go hand in hand. Furthermore, his renowned "working class" scorn for intellectuals - not only shown by the ideas he expressed in his writings, but also by his own way of life - would have surely made him dislike the very idea of some university scholar in charge of writing a biography of him. In an interview, one of his brothers explained this quite clearly:

I know people who would come to him and they would say we haven't got our electricity bill paid, and he would say, right, and he would go down himself 
with them to ESB and he would pay the bill there and then [...] And he would pay their rent too - for people living in flats and corporation houses. He'd pay up all the rent for them. And this is all forgotten; people who don't know any of this, any of this socalled research with regard to Brendan never brought that into the public eye, never let the people know the humanitarism of Brendan Behan [...] And this is why, if there's going to be any recollection of Brendan Behan by the people of Ireland, it will come from the poor people. It won't come from, as he described himself, the intellectuals [...] The people whose bills he paid, the number of children he bought shoes for. (qtd. in Mikhail 284-5)

Autobiographical discourse is, in Brannigan's words, “controlled disclosure, by which the writer reveals particular masks and performances, but always retains something to tell" (160). In recounting one's own life, one could of course be sincere and still omit relevant details that would contribute to shaping some sort of a truth. A truth can be complete or incomplete. It can always be incomplete without for this being false. Moreover, any kind of relationship, no matter how intimate, always involves some seemingly sincere revelation of intimate thoughts, or, especially in art, the communication of a private message. Dominic Behan reminds us of somebody who, after a performance of Brendan's play The Hostage, asked the author what the message of his play was, and Brendan replied: "what the hell do you think I am, a bloody postman?"(188).

Literature, and fiction in particular, is no place for truth. In fiction, lies, truth, or even mistakes are hard to distinguish. ${ }^{3}$ Although autobiography cannot be described as pure fiction only, no doubt it shares many of fiction's tricks and techniques. A fictional statement can never be absolutely true due to the fictionality of fiction, whereas the degree of truth in an autobiographical statement depends on it being true, false, or incomplete in the first place. In other words, in autobiography the writer can lie and just be believed as if he were sincere all the same. 
The whole idea of an absolute truth in fiction, as well as in autobiographical writing, is then suspect, and this is even truer when jokes and irony are involved. Yet there are truths we just feel to be true, and this has more to do with our own perception of what may be true, rather than with the willingness of the writer/speaker to disclose anything of his own private life and experience. Such a perception of the truth often depends on the way in which it is told. Take for instance the statement "Roma is in Italy." This is no doubt true, although only in a relative way, given the existence of another Rome in Georgia, or somewhere near. However, one may even feel that it is worth committing oneself to the truthfulness of the above statement. Still, nobody will loose his temper with somebody else who is ready to swear that the Coliseum is in Normandy, for this might just be the effect of too much French wine. On the other hand, the statement "A.S. Roma is the best football team in the world" may of course be false, especially these days; and yet a very ardent supporter of A.S. Roma may well get angry with someone else who is ready to state bluntly that Roma is the poorest team around. This shows that a difference between statements is the degree of fervour with which they are, or can be, defended, and this does not depend always on their truthfulness, although very often it does. In other words, this helps us see why some people have always been ready to die for worthy ideas, like equality, solidarity, or the struggle against totalitarianisms, whereas only a few would take arms to defend the primacy of French champagne over Italian spumante. It also explains why Brendan Behan, a lover of all kinds of wine, was ready, at the age of sixteen, to put bombs in Britain to defend what he called an "Irish Workers' and Small Farmer's Republic," (Borstal 4) and why he was given a jail sentence for that.

To sum up, all statements, especially fictional and literary ones, can produce in the listener/recipient strong effects or no effects at all, and this often depends on

\footnotetext{
${ }^{3}$ See Eagleton 89.
} 
the way in which such statements are told, rather than just the actual message they convey. In this context, where fictional and autobiographical truth are kept apart by an unstable divide increased by the abundance of comical interludes and jokes, in what follows I am going to analyse the second chapter of Confessions of an Irish Rebel in order to discuss the way in which Behan alternates funny accounts and tragedy in his own autobiographical reports.

Despite the few jokes, the event narrated in the second chapter is one of the most moving in the whole book. It comes just after the aforementioned noisy recollection of the drinking escapade with a British police officer, after Brendan's release from Borstal. Such curious events had ended with Brendan being deported to Ireland. There, he is welcomed by an immigration officer who asks him if he has a travel permit; to which he answers by handing him his deportation order. The officer wonders at the kind of document he has presented, and asks Brendan whether he is Irish, to which he responds: "No [...] as a matter of fact, I'm a Yemenite Arab" (23).

In the second chapter, Behan tells us of the first meeting with his family in years, and how his mother related to him all the recent gossip and news. After such exchanges of information, she adds: "Maureen is dying from consumption" (ibid. 25). The bluntness of the statement serves undoubtedly both as a trick to divert the attention of the reader to a dimension of intimacy, and as a dramatic pretext to interrupt the comical and somehow relaxing atmosphere carefully built in the preceding pages. Apparently, Maureen and Brendan, who are both introduced as persons coming from the same working-class background, have been sharing an intimate relationship in the past. After receiving the sad news, Behan seems to speak of the nature of that relationship somehow candidly:

Hell and heaven and despair and presumption and hope. We had talked together, laughed together, done the things the young boys and girls do 
together. I had been in this girl's house and I knew her father, her mother and her brothers. I'd fought alongside her brothers and we had shared the same battlefields of the poor.

How could death come to one so young? (ibid. 25)

Such apparently frank admissions serve, as I said, to establish the coming confessions as intimate ones. They have to be distinguished from those in the book that concern a more public sphere, such as Behan's politics or his involvement in revolutionary activities. In the passage, the two dimensions, private feelings and political views, are strictly interlinked, as in the statement about having shared "the same battlefields of the poor." By the way, the sentence also proves wrong those who questioned Behan's political ardour in his later years and suggested that he died politically disillusioned. It substantially demonstrates that he remained true to his views. As Declan Kiberd explains, Behan was "in his origins a socialist as well as a republican," (520) and apparently he stayed so up to his death.

A few paragraphs below, there come again new jokes and funny accounts. Thus, we automatically face a shift from a sort of sentimental recollection to a comical interlude. Behan goes to visit Maureen one Friday, and she asks him what he would like for his dinner. Brendan knows that fish was scarce those years, and decides to tell her a lie. He therefore claims to be Protestant and asks for a steak. Later on, although we are not given any precise temporal coordinate, she discovers that he is not a Protestant, and rebukes him for having sold Jesus Christ for a pound of beef.

The event is indeed unlikely to have happened at all. Given her intimate relation, Maureen must have known that Brendan was not an IRA Protestant, if such a thing exists at all. This shows that confessions, no matter how sincere in their external form, can never imply truth due to their structural nature of textual utterances. Besides, they silently suggest that narrators are always to some extent 
liars. The comic interlude ends with Behan's offer to paper the walls of Maureen's home. On that occasion he impersonates a professional liar ready to lie shamelessly also with regards to serious political questions. He explains that "we fell into talking about this and that and me telling her stories of great bravery for the cause in England and her sitting there and taking it all in" (Confessions 26).

Something similar happens when Behan goes to visit Maureen in the sanatorium. Being by his own admission "a coward by nature," before going there he "had to take a couple of drinks" (ibid. 26). At the end of the visit, and after having kissed Maureen on the lips for the last time, he admits to the fact that he has indeed been in the presence of death. This makes him decide to leave and go to the Embankment bar for one more drink.

Here drink is of great help. It does not make one forget, but rather helps one to face the crudity of life by diluting it partly. This happens also with good whiskeys, which need at times the help of a drop of water to become smoother. In the bar, Behan, in pardoning fashion, "reflected sadly on the words of Shakespeare, a very great Englishman, who said: 'Play the man.' He didn't say, 'Be a man,' he only said, 'Play the man'” (ibid. 27). The process of attaching such importance to performances, and therefore to lies which turn into surrogates for truths, is characteristic of Behan's narrative and playwriting. It inevitably undermines also the faithfulness of his own autobiographical accounts. This may partly account for his need to always live up to his reputation, which made him become eventually a sad example of the stage-Irish, in his later years. And yet, such an accepted and perfect disguise may be just the result of the harshness of his past experiences. As Rae Jeffs suggests in commenting on Behan's fondness for personal assault and disorderly behaviour in his later years in her preface to Confessions: 
He did not dare reveal that the ugliness of his experiences - death, bloodshed, and prison routine had not really touched the vital part of him. His essential being was strangely unaffected by the many painful events in his life, and this cloak of violence and abuse was necessary to hide his vulnerability. When the strain of impersonation became too much, a bout of drinking would follow the best soporific of all. (ibid. 9)

After the visit to the sanatorium, Behan goes to the house of Maureen's grandmother. When she enquires about her granddaughter, he replies in lying fashion that she is okay. Later on, when the old woman asks him would he have a cup of coffee, in spite of the fact that "coffee is a drink I particularly detest," he has not the courage to refuse. Such a sociable gesture, which implies an ironical acquiescence to the desires of an old lady in the very moment when all he wanted was to be left alone, makes him think of the forced solitude suffered while in prison:

It is great to be on your own for a bit, in the sun, for this is something you never are in prison for all their solitary confinements and I had had my share of those. The fughpigs watched you every moment and even at such times when the worst of us would give a dog privacy. (ibid. 27)

Brendan follows the old woman into the house and stays there waiting for Paddy, who is her son, the father of Maureen, and also an IRA comrade of him. In the meantime, he speaks with her of anything but the condition of Maureen, and this is because, as he himself states: "I have never been able to talk about things that mean a deal to me" (ibid. 28). When things mean a lot, one way out is mocking at them. In fact, when Paddy comes home and asks about his daughter's health, this time Behan, using a British slang expression, whispers to him: "I think Maureen has bought it," (ibid. 28) meaning that there isn't any hope for her. The bluntness of the admission and the colloquial expression itself both jar strikingly with the 
desperateness of poor girl's situation, and contribute comical and farcical tones to the sad recollection. In fact, despite Brendan's efforts to keep the truth from the old woman, when the two men tell her that they are going to the pub for a drink, she immediately becomes aware of what is actually going on, and asks again about her granddaughter. At this point, all Brendan can do is utter one of his own half-truths: "Look [...] maybe she is not so well" (ibid. 29). The old woman starts weeping, and the two adult men, showing little courage or compassion, leave her alone to her grief.

The end of the episode is a sad one. The men start drinking and crying in the bar, and then Brendan sings a moving song about the resting place of rose-lipped maidens and light-foot lads. The last words of the chapter are a most powerful epitaph:

I did not see Maureen again and that is all I want to say about it. But I wish to God she was with me today.

And if these are the confessions of an Irish rebel, they are indeed confessions. (ibid. 29)

If one manages to imagine the scene of their recording, and the sick man of almost forty, with no intention of dying but self-conscious of his fatal physical decline, who said those words, one has indeed the full impression of being in the presence of sincerity. If we compare this private admission to the final address to his wife, in the last sentence of the book - that is, "I've been faithful to thee, after my fashion" (ibid. 259) - we cannot fail to see the distance between the two utterances. Perhaps, we would be inclined to give more credit to the one about Maureen, for it looks a little more sincere. But of course, given Behan's established lying fashion, we are left wondering if there is any truth at all in such seemingly direct and candid utterances. 
Later on in the book, one more statement produces the same kind of effect. It occurs when Behan is informed that he will be released from prison, after he has shot two policemen in the Glasnevin area in Dublin. It might be recorded that he missed them by some fifteen yards, and his father, in commenting on the fourteenyear sentence inflicted to him, famously remarked that the judge had given him almost a year for each yard. However, the following admission is very much similar to the one about the poor girl with whom Brendan was in love:

When I knew I was going to be free again, I knew I was going to be free again to hunger and to poverty and to no kind of pyjamas, not even Free State Army ones. But I knew also I was free to the lights of my native city, which are very large and welcoming, and oh! I don't know - I was young at the time for Jesus' sake. Winter didn't bother me as it does now. It is always winter in Dublin. (ibid. 81)

Here we find sadness, and are tempted to see some kind of sincerity in Behan's statement, especially if we picture the scene where the following confession was recorded, and the sick man who made it. And yet, one cannot fail to spot also some kind of irony in the reference to the other side of freedom, as well as in the taking of God's son name in vain. This alternation of smiles and sorrow, of pain and provocative wit, is perhaps the legacy of one of the last Irish storytellers, a man who was capable of saying to a nun present at his death-bed: "May you be the mother of a bishop."

\section{Works Cited}

Behan, Brendan. Brendan Behan's Island. London: Hutchinson, 1962.

---. The Complete Plays. London: Methuen, 1978.

--. Borstal Boy. London: Arrow, 1990. 
---. Confessions of an Irish Rebel. London: Arrow, 1991.

Behan, Dominic. My Brother Brendan. London: Four Square, 1965.

Brannigan, John. Brendan Behan. Cultural Nationalism and the Revisionist Writer. Dublin: Four Courts Press, 2002.

Eagleton, Terry. After Theory. London: Penguin, 2004.

Farquharson, Danine. Prison Wrtings. Oxford: Inter-disciplinary Press, 2003.

Kearney, Richard. Navigations. Dublin: The Lilliput Press, 2006.

Kiberd, Declan. Inventing Ireland. London: Vintage, 1995.

McCann, Sean, ed. The World of Brendan Behan. London: Four Square, 1965.

Mikhail, E.H., ed. Brendan Behan - Interviews and Recollections. London, 1982

O'Connor, Ulick. Brendan Behan. London: Abacus, 1993.

Waugh, Evelyn. Decline and Fall. London: Chapman and Hall, 1928. 